\title{
Legal Benefit: A Comparative Study between Legislation and Islamic Jurisprudence
}

\author{
Shams El-Din Qassem Al-Khazaleh ${ }^{1}$ \\ ${ }^{1}$ Irbid National University, Irbid, Jordan \\ Correspondence: Shams El-Din Qassem Al-Khazaleh, Irbid National University, Irbid, Jordan.
}

Received: February 7, 2018

Accepted: March 14, $2018 \quad$ Online Published: November 30, 2018

doi:10.5539/jpl.v11n4p102

URL: https://doi.org/10.5539/jpl.v11n4p102

\begin{abstract}
The study dealt with the legal benefit in both: the legislations, specifically the Jordanian law, and the Islamic jurisprudence through the jurisprudence magazine. The study dealt with how to deal with the legal benefit in these legislations to reach the result of a discrepancy between these legislations and Islamic jurisprudence, it concluded that what is stated in Islamic jurisprudence is the best to apply. Results also showed the following:

- the Jordanian legislator did not provide for taking it into any of the unified or dual legal systems if the work is mixed, which caused a difference in the provisions of the judiciary

- The texts related to interest in Jordan are texts distributed between the Ottoman Murabaha system, the law of usury, the Jordanian trade law, the law of the Central Bank of Jordan, the Jordanian civil law and the Jordanian Code of Civil Procedure.

- All of the laws referred to above allow for the application of interest except the Civil Code, as article 640 states that: "If the loan contract provides an additional benefit to the contract, it is only to document the lender's right to the condition and validity of the contract", that is, the interest rate in loans is not considered.

- The provisions of the special laws referred to in respect of interest are applicable, without regard to the title of either party to the contract (that is, whether a trader or a non-trader), without regard also to the transactions of the parties to the contract by commercial transactions or related to the merchant's business needs or not related to those transactions especially considering some of the provisions of these special laws acts of banks as a commercial operation of banks and their customers.
\end{abstract}

Keywords: legal benefit, legislation, Islamic jurisprudence, Jordanian Law

\section{Introduction}

It is legally known that the benefits are expressed as legal compensation and are divided into two parts: the benefits of delay and compensatory benefits. The Dictionary of Law defines interest as: an amount calculated as a percentage on a presumed or payable capital, with each payment being paid annually as a wage from the deprivation of capital or waiting for it ${ }^{1}$.

The analogy between interest and usury in Islamic jurisprudence has been the subject of disagreement between the majority who forbid interest and the few who permit it, especially the banking interest. The reason for this difference is the difficulty of usury. ${ }^{2}$ The law distinguishes between interest and usury as the law permits the interest. The Jordanian Penal Code guarantees a manslaughter and articles 647 until the end of 652 punish the perpetrator of usury by sentenced to imprisonment.

The legislation distinguishes between interest and usury. Interest is considered to be the price specified by the law, which should not be exceeded. If this price exceeds the legal limit, it is considered usury ${ }^{3}$.

The Jordanian Civil Code prohibits interest payments. This prohibition is particularly evident in the text of Article 640 of the same law, which states that "if the loan contract provides an additional benefit to the contract, only the lender's right to the condition and validity of the contract shall be documented" Excess benefit includes

\footnotetext{
${ }^{1}$ See Mahmoud Khatib, Interest in Contemporary Economic Systems, Master Thesis, Institute of Islamic Studies Cairo 82, p. 126.

${ }^{2}$ Ahmed bin Hanbal, Musnad Imam Ahmad, Dar al-Kuttab al-Alami - Beirut, 2008, Vol. 9, pp. 4

${ }^{3}$ Jamil Cherkaoui (1977) Lessons in the General Theory of Commitment (Provisions of Commitment), Book II, Dar al-Nahda al-Arabiya, p. 66.
} 
interest and any other benefit that the lender obtains because of the loan, except for what is documented (such as the placement of an insurance property for the loan debt).

As well as article 480, paragraph 1, of the Jordanian Civil Code, which states: "A sale may be made in a murabaha, dilutive or subordinated manner if the selling capital is known at the time of the contract. The amount of the profit in Murabaha and the amount of loss in the inferiority is specified. The same article states that: "If it appears that the seller has increased the amount of capital to the buyer to reduce the increase," and this latter provision is excluded for interest in the sale, because any increase in the selling methods referred to (Murabaha, Al-Wadihah, and Tawliah)Is a surplus benefit without charge, the sale of Murabaha must be capital plus an agreed profit, and Al-Wadihah is the inferior sale of less than the capital amount agreed, and the Tawliah is a sale with the amount equivalent of capital without increasing or decreasing, that is the Civil Code - which is derived from the provisions of Islamic law -Interest is denied as interest is usury. ${ }^{4}$

It is clear from these texts that the position of the Jordanian legislator was not explicit and firm in its prohibition and proscription of benefits as did the Kuwaiti legislator when article 305 of the Civil Code No. 67 of 1980 prohibits and proscripts benefits of all types and forms

\subsection{Research Problem}

Investigating the legal benefits is one of the topics that are of great importance in the practical life. The legislations differed and they took different positions, but where did the Jordanian legislator stop? This is what we will answer in this research.

\subsection{Research Purpose}

This study aims at investigating the difference between the legislation and Islamic Jurisprudence when dealing with legal benefit, and to distinguish between interest and usury.

\section{Methodology}

The researcher will follow the analytical descriptive method of the relevant laws to address the problem of the study.

\subsection{The Position of the Arab Legislations on the Issue of Interest}

Before discussing the Jordanian legislator's position on the subject of interest we should review briefly the position of the Arab blogs on this subject. There are two different trends in the Arab blogs on the subject of interest, one of which is influenced by the French project, the Egyptian civil legislation and the other Arab civil legislation; another trend derived its provisions in this subject of the provisions of Islamic law.

It should be noted that most of the texts that regulate interest in Arab civil legislation have not left them without limitation, but have set the interest rate. Some of them have made the interest in civil matters a different price in commercial matters, which may mean that the authors of these texts do not want to leave room for judicial process to lose or increase that interest. But some of the legislations set a higher limit of interest that cannot be exceeded, and may be the result of those restrictions to the view of such legislation to interest as usury narrowed it and Arab civil codes in this area can be classified to the following:

\subsubsection{Arab Legislations That Discriminate against Interest and Its Provisions}

This legislation may be similar to that of the French candidature. The legislation is in both directions:

2.1.1.1 The first is the legislation that allows for absolute interest, such as the Lebanese obligations and contracts and the Tunisian contract magazine.

1) The Law of Lebanese Obligations and Contracts: This law was adopted in the first paragraph of Article 26, where it went in the second paragraph of that article to give the creditor the right to demand supplementary or additional compensation for damages caused by the debtor due to his non-payment of debt on the specified date and has a bad intention, as well as the Lebanese legislator in Article (766) make the loan contract with interest if it is provided for.

2) Journal of Tunisian Obligations and Contracts: It may also take the system of interest from what is stated in the original article in the loan contract in Article 1056 - between non-trading individuals is to donate only if the interest is written.

\footnotetext{
${ }^{4}$ Al-Azizi, M. (2001) Islamic Shariah Investment and Banking Services carried out by Islamic banks, Al-Furqan Publishing and Distribution
} 


\subsubsection{It is the legislation that allows interest restrictions, including:}

1) Egyptian Civil Code: It dealt with the issue of interest in article 226-233 of the Civil Code. These provisions show that the Egyptian legislator narrowed interest rates by imposing restrictions on the entitlement of those benefits, such as not exceeding the legal limit, and not exceeding the capital charge and prohibiting the compound interest from what is required in article 542 to the borrower to pay the agreed benefits. At maturity, if not agreed upon. On maturity, if there is no agreement on interest, the loan shall be repaid without charge.

2) Syrian Civil Code: The Syrian legislator organized the interest in articles 227-234 and article 12 thereof, these texts correspond to what is stated in the Egyptian Civil Code except that the Syrian legislator has set the maximum interest rate at $9 \%$, while the Egyptian legislator has set it at $4 \%{ }^{5}$.

3) Iraqi civil Code: The Syrian legislator organized interest in articles 171-176 which is similar to the provisions of the Egyptian legislator except for the Iraqi civil law provided that the place of commitment to the benefit of the interest amount of money is limited amount at the time of the emergence of the obligation, in as much as the Egyptian legislator required to be limited at the time of payment, thus the Egyptian legislator differs from the Iraqi legislator in terms of interest rate. The Iraqi legislator did not give the judge the right to reduce the interest if he caused a bad intention in the creditor and he claims that he is entitled to prolong the dispute for a period that has long been unjustified. Otherwise, the texts of the two laws are similar including the loan contract as Article 692 civilians.

\subsubsection{Arab Legislation, Which Deprived the Interest of a Relative Deprivation}

This is the trend of Algerian and Moroccan lawmakers. In article 186, the Algerian legislator created an alternative to the legal benefit, where compensation for the delay in fulfilling the obligation was recognized if the obligation was a sum of money, as did the rest of the other legislation. However, he left the estimate of this compensation to eliminate the dispute of the legislation that had already been submitted to it where it issued itself to determine the amount of legally known that the benefits are expressed by legal compensation, it is divided into two parts: the benefits of delay and compensatory benefits. The Dictionary of Law defines interest as: an amount calculated as a percentage on a presumed or receivable capital, with each payment being paid annually as a wage for depriving it of its capital or waiting for interest.

However, the Algerian legislator deliberately prohibited the benefit among individuals in its article 454. But in Article 455 and Article 456, it permitted the interest of financial institutions to deposit funds or grant loans. As for the Moroccan legislator, the Moroccan law of obligations and contracts prohibited interest rates among Muslims. In article 870, the requirement of interest among Muslims is considered null and void for the contract that it includes, whether it is explicit or in the form of a gift. The text denied the benefit to Muslims only, and in article 871 it was stated that, in other cases, interest is only entitled if it has stipulated in writing and assumes this requirement if one of the parties is a trader. What applies to the former legislation applies to the Yemeni Civil Code of 1992, which in principle was denied in principle in article 363 and then repealed in articles 126 and $963^{6}$.

2.1.3 Arab Legislations that Are Interest Free, and Are As Follows:

1) Kuwait's Civil Code in Articles 305 and beyond, in which the Kuwaiti legislator cited an alternative to interest, is judicial compensation in which justice is respected, and article 547 of the presumption is useless.

2) UAE Civil Transactions Law in Articles 712 and 714, which conforms to the provisions of the Jordanian Civil Code and is taken from it.

3) Law on Sudanese Transactions in Articles 287-281.

4) Jordanian Civil Law, which will be discussed in detail.

\subsection{The position of the judicial judgments, the Murabaha and the law of usury.}

The position of both the Code of Justice and the Murabaha, and the law of excessive usury on the subject of interest

\subsubsection{Journal of Justice and Interest}

Under the provisions of the Islamic Sharia, which prohibits usury in ordinary and commercial codes, the Code of Legal Judgments as a general law prior to the promulgation of the Jordanian Civil Code in 1976 did not address

\footnotetext{
${ }^{5}$ Abdel Halim Nour, op. Cit., P. 24.

${ }^{6}$ See on the Yemeni Civil Code of 1992, Dr. Wahiduddin Sawar, General Trends in Jordanian Civil Law, op. Cit., P. 302
} 
the interest in its texts. However, under the pressure of need and the new circumstances and the association of commercial interests between the nationals of the foreign state, the privileges of those foreigners, both on the territory of the Ottoman Empire and those who deal with them from outside their borders, began to appear. In response to these developments, the Ottoman legislator was forced to recognize the interest and issue the Ottoman Murabaha system ${ }^{7}$, dated at 9 Rajab 1304 and 22 March 1303, the Murabaha Law of 9 Rajab 1304, and the Ottoman Murabaha Law of 22 March 1303.

\subsubsection{The Ottoman Murabaha System}

The Ottoman Murabaha system has been in force since (1903), and its provisions are still in effect. These provisions include:

1) The rate of interest under this system does not exceed $9 \%$ per annum under the first article of it, and this is what will be discussed when talking about the interest rate.

2) This system prevents the amount of debt capital (m4) from exceeding the interest over time. Under this provision, rulers are prohibited from ruling on interest beyond capital, which includes both commercial and non-commercial transactions ${ }^{8}$. In doing so, the Court of Cassation ruled that the plaintiff has no legal benefit from the date of the case until full payment as long as the court has ruled him with interest equal to the value of the capital ${ }^{9}$.

\subsubsection{The Law of Obscene Usury}

In 1934, the obscene usury law No. 30 of 1934 was issued. The legislator did not specify in this law the meaning of obscene usury, but he concludes from the first paragraph of Article 2 of this law that the obscene usury is the obscene interest that exceeds the rate permitted by the law, and the legislator in this law did not regulate the interest and did not specify its rate, but only dealt with the question of charging the obscene interest by giving the court the right to flow in the presented transactions, and to hold the accountability between the creditor and the debtor and to exempt the debtor from paying any amount in excess of the amount awarded despite the existence of any account or concession or agreement between the creditor and the debtor.

Some jurisprudence ${ }^{10}$ have pointed out that this law applies only in the West Bank, but the researcher did not find in the provisions of this law what is limited in its application to an area without others, considering that the unit existed until the legal and administrative disengagement in 1989.

\subsection{The Position of the Jordanian Civil Code of Interest}

The Jordanian Temporary Civil Code was issued on May 23, 1976, and was approved in 1996, and many of its provisions have been derived from Islamic jurisprudence, especially the Hanafi jurisprudence. Jordanian civil law is considered a historical source for many Arab civil codes, Such as the UAE Transaction Law and the Unified Arab Law. The Jordanian legislator was influenced in his texts by the Islamic jurisprudence, we have to note that the Jordanian legislator has taken a negative stance, rejecting the issue of compensation for delay ${ }^{11}$. The explanatory note to the mentioned law stated that "the obligation of the debtor to pay compensation on the basis of compensation for what he caused by the avoidance of harm was not the loss of money permitted by the jurisprudential rules and the legal principles that taking money is not only a donation or an interview with money taken or damaged and if it was void for him because the basis of compensation in the opinion of jurists is the exchange of money with money .... "On the subject of interest, the law considered that the loan is considered a donation, Article 638 states the following:

1) The borrower is required to be eligible to donate.

2) The guardian does not have the right to borrow money from those in his or her guardianship.

Article 640 states: "If a loan contract stipulates additional benefit in the contract, it is only to document the borrower's right to the condition and validity of the contract.

Dr. Salah Al-Din Al-Nahi and in a research published in the Research Annex at the Bar Association, entitled

\footnotetext{
${ }^{7}$ Muflih Aql, Managing Interest Rates under Floating, Journal of Banks in Jordan, No. 3, 1995, p. 1607

${ }^{8}$ Rights Discrimination 200/87, Journal of the Bar Association, 1990, p. 827, see Rights Discrimination No. 92/78, Journal of the Bar Association, 1978, p. 877.

${ }^{9}$ Rights Discrimination No. 206/80, Journal of the Bar Association, 1981, p. 342. Also the distinction of rights No. 149/91, Journal of the Bar Association, 1993, p. 199

${ }^{10}$ Aqel, M. (1990) Managing Interest Rates under the Correction, op. Cit., P. 607

${ }^{11}$ Dr. Wahiduddin Siwar, General Trends in Jordanian Civil Law, Dar Al-Thaqafa Publishing House, 1st edition 1996, p. 277.
} 
"Provisions of Commitment" that "the Jordanian legislator has not been subjected to legal benefit and has not recognized it and has not set a higher price." ${ }^{12}$ The reader of the previous statement comes to understand the saying that the Jordanian legislator did not benefit the law but he has remained silent about it, and the saying that he did not recognize it to be denied, but the same jurisprudence and in another subject of his research stated that the Jordanian legislator has resigned from addressing the legal benefit ${ }^{13}$.

In contrast to these previous doctrinal views, we find that there are doctrinal opinions that have gone to the contrary and can be limited with the following:

1) Dr. Ahmed Ziadat and Dr. Ibrahim Al-Amoush ${ }^{14}$ argue that the origin of civil transactions is that interest is not permissible and they relied on the text of Article 640 of the Civil Code, where they consider that the excess benefit referred to in the text includes interest.

2) Professor Wahba al-Zoghaili in his explanation of the text of Article 640 that every loan brings benefit is forbidden as usury and interest as we know is usury ${ }^{15}$.

3) Professor Buthaina Abdullah Khalil argues that the Jordanian Civil Code does not recognize the benefit in the text of article 640, because Islamic law does not recognize the interest whatever it may be, and consider it usury which it forbidden strongly ${ }^{16}$.

It appears to us from the previous jurisprudence that there are two different doctrinal trends on the subject of interest in Jordanian civil law:

2.3.1 The First Trend Is That The Jordanian Legislator Has Remained Silent about the Issue of Interest in the Law of the Victim

\subsubsection{The Second Trend Is That the Jordanian Legislator Prevents the Interest and Deprives It}

This first trend of jurisprudence is considered by the researcher for the following reasons:

1) That the legislator has stated in Article 638 which is one of the provisions that the contract was a donation, since the meaning understood by the texts mentioned that the contract is without any benefit.

2) That the legislator has canceled the condition of excess utility in the loan contract and considered it as if it was not and the condition of the excess benefit contained in Article 640 is interest.

3) What we referred to is supported by what is in the explanatory note to the Civil Law, which was mentioned earlier in this paper.

4) The jurisprudential opinions expressed in this regard have been concise, which may explain from the point of view of the researcher to the lack of knowledge of the previous two texts.

5) That some of these doctrinal opinions have gone when talking about and classification of the Arab blogs to refer to the Jordanian Civil Code within the title of the Arab blogs that prevented the interest, which may be a confirmation of the validity of the second trend or return from previous diligence ${ }^{17}$.

6) That some of the jurisprudence represented by the first trend went in his explanation of the UAE Civil Transactions Law, in particular Article 712 of which conforms to Article 638 and 640 of the Jordanian Civil Code, that the prohibition of the UAE legislator of interest is implicit in the consideration of the loan as a donation ${ }^{18}$.

It should be noted that the Jordanian legislator has denied interest, even if it is not explicitly stated. It does not mean that the Jordanian legislator in the Civil Code forbidden of the benefit that this system does not exist in Jordanian civil legislation, As there are many texts contained in special laws have been referred to and regulated provisions, and we know that when the conflict of those special texts with the provisions of the Civil Code, the common law, these texts are applied, in addition, the legislator of the Jordanian Civil Code referred in Article $1448 / 2$ to respect the provisions of any special law when the text of the law states that: "In the application of the

\footnotetext{
${ }^{12}$ Dr. Salah Alnasi (1985) the provisions of commitment, an analytical study of the budget, research in the Journal of the Bar Association, Research Appendix No. $19 /$ K, p. 82.

${ }^{13}$ Ibid., P. 83.

${ }^{14}$ Ahmed Ziadat and Ibrahim Al Amoush, Brief in Commercial Legislation, Publications of the Institute of Banking Studies, p. $23,1995$.

${ }^{15}$ Dr. Wahba al-Zajaily, op. Cit., P. 199

${ }^{16}$ Buthaina Abdullah, The seller's commitment to delivery in international sales contracts, Master thesis, University of Jordan, 1995 , p. 217.

${ }^{17}$ Professor Wahiduddin Siwar, General Trends in Jordanian Civil Law, op. Cit., P. 304.

${ }^{18}$ Dr. Wahiduddin Siwar, General Trends in the UAE Civil Procedure Law, Al-Mutanabi Printing House, Al Ain, United Arab Emirates, 1988 , p. 296 , p.
} 
provisions of this law, the provisions of the special laws shall be took into consideration ".

These texts include the provisions of the Jordanian Trade Law No. 12 of 1960, the provisions of the Ottoman Murabaha Law, the Central Bank Law No. 19 of 1979, and the Code of Civil trials.

\section{Conclusion}

Finally, we must show that despite the manifestations of strictness in the Jordanian civil law in the prohibition of interest, and the absence of exceptions to the principle of the prohibition of that interest in its texts, as some of the comparative Arab legislation did and despite going to prohibit all compensation for the delay of commitment in absolute terms, the Jordanian legislator has organized the topic of interest in many special texts, such as the Code of Civil trials and the Ottoman Murabaha system. Moreover, the Jordanian legislator did not make taking a benefit beyond the legal limit a crime punishable by law, as some other legislation has done.

It seems to the researcher after these observations that the legislator has tolerated - except as stated in the Civil Code - the issue of interest.

\section{Recommendations}

In the light of previous findings, the researcher recommended the following:

- The Jordanian legislator should add a text to the Jordanian Trade Law so that the Commercial Law becomes the law applicable to the hybrid business, in order to settle the dispute between the creditor and the debtor on the interest.

- We hope that the Jordanian legislator will consolidate the interest-related legislation with a single law setting out the bases, criteria and conditions for interest.

- Amendment to paragraph (2) of Article (1448) of the Civil Code stipulates that: "In the application of the provisions of this law, the provisions of the special laws shall be taken into account", because it is this paragraph that makes the provisions of the laws granting the interest applicable as special laws for the Civil Code, and to add a phrase which we propose to read as follows: "Provided that the provisions of those special laws do not conflict with the principles established in this law" and the amendment we propose leads to the non-application of interest to civil works for its parties as - the interest - In the civil law that deprives interest, and applying the sources of civil law, especially the provisions of Islamic jurisprudence and the principles of Islamic law.

- If it is necessary to recognize the right of the banks to obtain interest for the loans they make in their banking activities, considering that such business is in the business judgment, even if the purpose of the loan is not commercial, and if the trader is in transactions for which the business is commercially seeks to obtain interest as - from the point of view and the view of many people - in the necessity of nullification or that its interests require the adoption of it, it is necessary to add the text of the article to the Jordanian Trade Law, which includes consolidation of the legal rule applicable to interest in commercial and non-commercial loans

\section{References}

Abdullah, B. (1995). Seller's Commitment to Delivery in International Sales Contracts, Master Thesis, University of Jordan.

Al-Azizi, M. (2001). Islamic Shariah Investment and Banking Services carried out by Islamic banks. Al-Furqan Publishing and Distribution.

Al-Badrawi, M. (1986). The General Theory of Obligations, Part Two, 1986 Edition.

Al-Far, A. (2010). Provisions of Commitment (2nd ed.). Dar Al-Thaqafa Library, Amman.

Al-Hamza, A. (1980). The Case from Beginning to End (2nd ed.).

Al-Hindi, A., \& Jasser, M. (1982). The Origin and Development of the Banking System in Jordan. Institute of Banking Studies, Central Bank of Jordan, Jordan Press.

Al-Khatib, M. (1982). Interest in Contemporary Economic Systems and the Ruling of Islam, Master Thesis, Institute of Islamic Studies, Egypt.

Al-Nahi, S. (1985). Provisions of Commitment. Journal of the Bar Association, Research File No. 19/ K, 1985.

Al-Zoghaili, W. (1978). Contracts in the UAE Civil Transactions Law and the Jordanian Civil Code, Dar Al-Fiker, $1^{\text {st }}$ edition.

Aqel, M. (1990). Management of interest rates under correction. Journal of Banks in Jordan, (6).

Aqel, M. (1995). The rationality of the interest rate margin of Jordanian banks. Journal of Banks in Jordan, (3). 
Baker, I. (1982). Personal Guarantees and Bank Guarantees. Publications of the Institute of Banking Studies, Central Bank of Jordan.

Cherkaoui, J. (1977). The General Theory of Compliance Commitment Provisions, Second Book, Dar al-Nahda al-Arabiya.

Explanatory note to the Jordanian Civil Law.

Fadel, M. (1995). The General Theory of Obligations in Civil Law, section 2, Provisions of Commitment, Dar al-Thaqafa Library, $1^{\text {st }}$ edition, 1995.

Jordanian Civil Law.

Journal of the Jordanian Bar Association, several issues.

Nour, A. (1991). Legal Compensation in Egyptian Civil Law and Islamic Law, PhD Thesis, Cairo 1991, p.18.

Sami, F. (1994). Principles of Commercial Law, part.1, House of Culture, $1^{\text {st }}$ edition.

Sharaf al-Din, A. (1980). The Extent of Legitimacy of the Benefits of Delay and the Constitution of its Texts, Research published in the Journal of Law and Sharia, Faculty of Law, Kuwait University, No. 4.

Siwar, W. (2001). General Trends in Jordanian Civil Law. Dar Al Thaqafa for Publishing and Distribution, Amman, Jordan.

Sultan, A. (1983). Provisions of Obligation, Summary in the General Theory of Commitment, Comparative Study. Dar al-Nahda al-Arabiya, Beirut.

Zaki, M. (1978). The General Theory of Commitment in the Egyptian Civil Law (3rd ed.).

Ziadat, A., \& Al- Amoush, I. (1995). Brief in Commercial Legislation. Publications of the Institute of Banking Studies.

\section{Copyrights}

Copyright for this article is retained by the author(s), with first publication rights granted to the journal.

This is an open-access article distributed under the terms and conditions of the Creative Commons Attribution license (http://creativecommons.org/licenses/by/4.0/). 